\title{
INSEKTORAL PEMBANGUNAN PARIWISATA LOKAL DI PANGANDARAN : BUDAYA, KREATIVITAS DAN MASYARAKAT
}

\author{
Hendry Ferdiansyah, Awaludin Nugraha, Ute Lies Siti Khadijah, Evi Novianti \\ Magister Pariwisata Berkelanjutan Sekolah Pascasarjana \\ Universitas Padjadjaran
}

\begin{abstract}
ABSTRAK
Desa Karangjaladri terletak di Kecamatan Parigi, Kabupaten Pangandaran. Desa Karangjaladri memiliki 3 dusun, yaitu Dusun Astamaya, Dusun Bojong Salawe dan Dusun Buniayu. Prinsip perencanaan dan manajemen berbasis masyarakat dalam pariwisata dapat memandu pariwisata kreatif karena menjadi alat untuk pembangunan berkelanjutan lokal. Ini dapat mendukung pariwisata kreatif untuk memberikan pengalaman yang benar-benar otentik melalui proses partisipasi, penciptaan bersama dan pembelajaran antara masyarakat lokal dan wisatawan. ). Sedangkan metode yang digunakan adalah metode deskriptif. Metode deskriptif adalah metode yang melukiskan variabel demi variabel, satu demi satu, mengumpulkan data secara univariat, dan data yang diperoleh melalui ukuran-ukuran kecenderungan pusat (central tendency) atau ukuran sebaran (dispersion) (Rakhmat 2009, 25). Hasil Penelitian Informasi kebutuhan informasi wisata sudah mampu memenuhi kebutuhan informasi seputar wisata Kota Bandung, meskipun belum semua informasi tersedia pada saat diperlukan. Informasi yang diberikan cepat diterima oleh receiver dan informasinya bersifat akurat, sehingga dapat memenuhi kebutuhan informasi seputar wisata Kota Bandung. Jumlah informasi yang diperoleh melalui kebutuhan informasi wisata sudah melengkapi semua informasi yang dibutuhkan, sehingga dapat memenuhi kebutuhan jumlah informasi wisata yang diperlukan. Kata Kunci : Informasi, Pariwisata
\end{abstract}

\begin{abstract}
Kecamatan Karangjaladri is located in Kabupaten, Pangandaran Regency. Kecamatan Karangjaladri has 3 desa, namely Dusun Astamaya, Dusun Bojong Salawe and Dusun Buniayu. The principle of planning and community-based management in tourism can guide creative tourism as it becomes a tool for local sustainable development. It can support creative tourism to provide a truly authentic experience through the process of participation, co-creation and learning between local communities and tourists. ). While the method used is a descriptive method. A descriptive method is a method that paints variables by variable, one by one, collecting data univariate, and data obtained through central tendency measures or dispersion (Rakhmat 2009, 25). The results of the information research needs of tourism information has been able to meet the needs of information about Bandung city tour, although not all information is available at the time of need. The information provided is quickly received by the receiver and the information is accurate, so as to meet the needs of information about Bandung city tour. The amount of information obtained through tourist information needs has already completed all the information needed, so that it can meet the needs of the required number of tourist information.
\end{abstract}

\section{A. PENDAhuluan}

Desa Karangjaladri terletak di Kecamatan Parigi, Kabupaten Pangandaran. Desa Karangjaladri memiliki 3 dusun, yaitu Dusun Astamaya, Dusun Bojong Salawe dan Dusun Buniayu. Desa Karangjaladri memiliki 33 RT dan 7 RW. Jumlah penduduk berjumlah 5571 jiwa, dengan jumlah laki-laki 2786 jiwa dan perempuan 2785 jiwa dan total KK sebanyak 2101. Desa Karangjaladri memiliki luas wilayah $394.950 \mathrm{Ha}$.
Batas-batas wilayah Desa Karangjaladri di sebelah utara yaitu Desa Karangbenda, sebelah barat : Sungai Cijalu (Desa Margacinta), sebelah timur : Desa Ciliang dan sebelah selatan : Samudera Hindia.

Dalam melaksanakan pembangunan yang dibutuhkan masyarakat partisipasi masyarakat lokal diperlukan untuk mencapai tujuan pembangunan berkelanjutan (Salazar, 2012). Salah satu alasan mengapa ada masalah dan dampak negatif di situs pariwisata adalah kurangnya partisipasi masyarakat dalam perencanaan 
dan pengelolaan (Tosun, 2000) yang merupakan masalah yang sama dalam pariwisata kreatif (Alvarez, 2010). Masalah komodifikasi akan terjadi di lokasi wisata kreatif karena kreativitas bersifat mobile dan dapat diproduksi di mana saja dan kapan saja, untuk 16 tahun misalnya, pertunjukan seni dan karya seni. Alvarez (2010) mempertanyakan tingkat keaslian dan budaya tradisional nyata masyarakat setempat ketika beberapa tujuan memiliki program untuk menyajikan pertunjukan lokal untuk menarik wisatawan. Selain itu, menciptakan daerah dan ikon baru untuk menarik para wisatawan yang benar-benar tertarik dengan kehidupan sehari-hari masyarakat lokal di kota dan dalam menemukan situs yang ditemukan dapat membuat destinasi memudar atau menjadi kurang dihargai. Maitland (2009) menunjukkan unsur-unsur keaslian dalam perspektif wisatawan kreatif dalam kasus Pangandaran ketika sebuah program diluncurkan untuk mempromosikan dan memperbaruinya dari wisata budaya ke kota kreatif. Pengalaman pariwisata kreatif berhubungan dengan kehidupan sehari-hari penduduk Pangandaran yang tinggal di Bojong Salawe dan Karangjalandri. Lingkungan dan rasa tempat, bangunan rata-rata dan kehidupan nyata adalah faktor keaslian. Konsekuensinya, manajemen pariwisata akan berhubungan dengan kehidupan masyarakat setempat. Masalah konflik juga dapat terjadi lebih mudah antara masyarakat lokal dan pemangku kepentingan luar yang bukan penduduk lokal tetapi perlu melakukan beberapa pekerjaan yang menerapkan kearifan lokal untuk menghasilkan produk mereka. Istanbul menghadapi masalah ini karena pemerintah tidak memperhatikan dampak pada daerah sekitarnya dan pada penduduk lokal ketika meregenerasi situs menjadi museum kota (Gezici dan Kerimoglu, 2010), Okazaki (2008) menegaskan bahwa perencanaan dan pengelolaan berbasis masyarakat masih merupakan alat terbaik untuk mengurangi dampak negatif dari pengelolaan pariwisata.

Prinsip perencanaan dan manajemen berbasis masyarakat dalam pariwisata dapat memandu pariwisata kreatif karena menjadi alat untuk pembangunan berkelanjutan lokal. Ini dapat mendukung pariwisata kreatif untuk memberikan pengalaman yang benar-benar otentik melalui proses partisipasi, penciptaan bersama dan pembelajaran antara masyarakat lokal dan wisatawan. Wisatawan dapat mencapai kebutuhan pengembangan diri dan kesenangan. Pada saat yang sama, masyarakat setempat dapat menerima manfaat dari pariwisata. Pertama, 17

citra pariwisata kreatif termasuk lokakarya, acara atau festival; lingkungan alam; infrastruktur dan fasilitas didasarkan pada keaslian masyarakat. Partisipasi lokal penting untuk mengakses dan mengembangkan sumber daya ini secara tepat (Murphy, 1985). Kedua, kekhawatiran lokal secara langsung mempengaruhi pengalaman wisatawan sebagai faktor penting dalam pariwisata kreatif. Wahab dan Pigram (1997) menemukan bahwa tujuan wisata harus dibuat dalam lingkungan yang harmonis di mana masyarakat setempat dapat memperoleh manfaat pariwisata tanpa merasa seperti mereka adalah korban. Ini akan, pada gilirannya, mendukung hubungan positif antara wisatawan dan masyarakat setempat. Ketiga, keterlibatan semua pemangku kepentingan dan masyarakat lokal sangat penting untuk mendorong generasi pendapatan jangka panjang dari pariwisata (Bovy, 1982) dan menjadi kekuatan pendorong untuk melestarikan area komunitas dalam hal budaya dan lingkungan sebagai produk pariwisata (Felstead, 2000). Banyak penelitian (Okasaki, 2008, Simmon, 1994; Tosun, 2000; dan Reid, Mair \& George, 2004) telah menegaskan pentingnya perencanaan dan manajemen berbasis masyarakat yang dapat mengadvokasi pembangunan berkelanjutan.

\section{B. TUJUAN PENELITIAN}

1. Untuk mengetahui akses informasi dalam memenuhi kebutuhan informasi wisata

2. Untuk mengetahui kecepatan informasi terhadap dalam memenuhi informasi wisata

3. Untuk mengetahui jumlah informasi yang diperoleh memenuhi kebutuhan informasi wisata

4. Untuk mengetahui keefektifan dalam memperoleh pengetahuan setelah mengakses dalam memenuhi kebutuhan informasi wisata.

5. Untuk mengetahui kesesuaian informasi dalam memenuhi kebutuhan informasi wisata

6. Untuk mengetahui motivasi untuk memahami dan menerapkan informasi dalam memenuhi kebutuhan informasi wisata followers.

\section{METODE PENELITIAN}

Definisi penelitian survei menurut Singarimbun, adalah "penelitian yang mengambil sampel dari satu populasi dan menggunakan kuesioner sebagai alat pengumpulan data yang pokok", artinya pengumpulan informasi dari responden dilakukan melalui kuesioner (Singarimbun 2012, 3). Sedangkan metode yang digunakan adalah metode deskriptif. Metode deskriptif adalah metode yang melukiskan variabel demi variabel, satu demi satu, mengumpulkan data secara univariat, dan data yang diperoleh melalui ukuran-ukuran kecenderungan pusat (central tendency) atau ukuran sebaran (dispersion) (Rakhmat 2009, 25). 
Dalam melakukan penelitian ini, peneliti menyebarkan kuisioner atau angket yang dikirim kepada responen. Peneliti juga melakukan wawancara Masyarakat Desa Karangjalagri Kabupaten Pangandaran dan beberapa responden serta melakukan studi pustaka dari beberapa sumber seperti buku, jurnal, serta artikel yang berkaitan dengan peneltian ini. Hasil dari pengolahan data tersebut akan menjawab pertanyaan peneliti mengenai pengelolaan industri kreatif dapat memenuhi kebutuhan informasi masyarakat seputar budaya, sejarah, serta tempat wisata dan hiburan yang ada di Kabupaten Pangandaran

\section{POPULASI DAN SAMPEL}

Pada penelitian ini yang menjadi populasi yaitu masyarakat Desa Karangjalagri yang menjadi populasi dari penelitian ini adalah mereka yang memiliki usaha kreatif yang menunjang pariwisata lokal di Kabupaten Pangandaran

Teknik pengambilan sampel dalam penelitian ini menggunakan Incidental Sampling, yaitu siapa saja yang ditemui dan masuk dalam kategori populasi, dapat diinterviu sebagai sampel atau responden

\section{E. TEKNIK PENGUMPULAN DATA}

Teknik pengumpulan data dan informasi dengan menggunakan beberapa tahap, diantaranya adalah:

1. Angket, adalah metode pengumpulan data yang dilakukan dengan cara memberi daftar pertanyaan yang disusun secara sistematis untuk diisi oleh responden. Angket akan dikirim oleh peneliti melalui e-mail, Direct Message (DM) kepada masyarakat yang menjadi responden pada penelitian ini

2. Wawancara, pada penelitian ini, peneliti melakukan wawancara langsung dengan informan yaitu orang yang terlibat langsung dengan industri kreatif

3. Studi Pustaka, adalah metode pengumpulan data yang diambil dari bahan pustaka yang telah ada sebagai referensi penelitian seperti buku, jurnal, artikel, dan sumber referensi lainnya yang bersifat teoritis guna menguatkan berbagai konsep, landasan, dan kerangka berpikir yang digunakan untuk menyelesaikan rumusan masalah yang terdapat dalam penelitian ini.

\section{F. HASIL PEMBAHASAN}

Selain itu, organisasi pendidikan dapat mendukung orang-orang profesional dalam membantu mendidik masyarakat lokal dan pengusaha seperti program pelatihan pemandu lokal dari Universitas Padjadjaran. Hasil pelatihan, manajemen pariwisata dalam hal pembangunan berkelanjutan lokal harus mengintegrasikan campuran organisasi untuk mencapai tujuannya. Khususnya, karena pariwisata kreatif berfokus pada wisatawan dengan minat khusus, studi tentang perilaku dan motivasi wisatawan, pengembangan kegiatan pariwisata, dan peningkatan partisipasi lokal adalah tindakan pertama untuk destinasi pada fase pengembangan awal. Kemudian, pemasaran dan hubungan masyarakat adalah alat penting untuk promosi dan komunikasi dengan wisatawan dan masyarakat setempat. Jaringan pemasaran dapat menangani masalah ini bagi masyarakat setempat karena mereka dapat mendukung sumber daya manusia dan dana untuk tujuan. Namun, setiap organisasi memiliki visinya sendiri; misalnya, beberapa rencana memiliki kerangka waktu yang terbatas atau harus mengubah tindakan sesuai dengan kebijakan pemerintah. Pada saat yang sama, mitra bisnis harus mengubah atau menciptakan kembali produk pariwisata yang dapat merespons wisatawan saat ini. Salah satu masyarakat (Nardi, 29 tahun) menjelaskan bahwa :

'Saya pikir kita sedang menghadapi masalah manajemen pariwisata karena jumlah wisatawan telah menurun sejak kepala biara sebelumnya meninggal dan konflik lokal meningkat ... Salah satu faktornya adalah tidak ada jaringan pariwisata yang cukup yang dapat mendukung beberapa hal yang tidak kita miliki, terutama pengetahuan tentang manajemen pariwisata dan anggaran pemerintah daerah untuk melakukan pemasaran jangka panjang. Dalam pandangan saya, sekarang hanya ada kantor pemerintah daerah yang masih bekerja dalam manajemen pariwisata. '

Akhirnya, berbagai jaringan pemasaran juga dapat mendukung konsep pembangunan berkelanjutan lokal yang berkelanjutan. Informasi mengenai pengembangan kreativitas menyajikan informasi setiap minggu sehingga informasi tersebut cepat diterima oleh masyarakat dan informasi yang disajikan bersifat akurat. Berdasarkan data penelitian, sebanyak 58 responden $(58,6 \%)$ menyatakan bahwa informasi yang diberikan pemerintah daerah adalah akurat, karena informasinya tidak menyesatkan, lengkap, dan jelas mencerminkan keadaan yang sebenarnya sehingga dapat dipercaya. Hal ini berarti informasi yang diberikan berkualitas. Seperti yang diungkapkan John Burch dan Gary Grudnitski (dalam Jogiyanto 2002, 10) mengenai keakuratan informasi.

"Akurat, berarti informasi harus bebas dari kesalahankesalahan dan tidak bias atau menyesatkan. Akurat juga 
berarti informasi harus jelas menerminkan maksudnya. Informasi harus akurat karena dari sumber informasi sampai ke penerima informasi kemungkinan banyak terjadi gangguan (noise) yang dapat merubah atau merusak informasi tersebut."

Jumlah informasi yang diberikan pemerintah daerah sudah melengkapi informasi yang dibutuhkan yaitu sebanyak 49 responden $(49,5 \%)$. Artinya, staf pemerintah daerah melakukan penyebaran memberikan informasi yang utuh tidak setengah-setengah sehingga mampu memenuhi jumlah informasi yang diperlukan. Kelengkapan informasi merupakan salah satu dari sepuluh sifat informasi, seperti yang dikemukakan oleh Sutabri $(2005,30)$ yaitu sifat luas dan lengkap.

Berdasarkan data penelitian, sebanyak 53 responden $(53,3 \%)$ menyatakan efektif dalam memperoleh pengetahuan setelah pemberian informasi mengenai keggiatan kreatif untuk meningkatkan pariwisata karena bisa tahu lebih cepat dan lebih banyak informasi seputar Kabupaten Pangandaran. Hal ini berarti informasi yang diberikan dapat menambah pengetahuan masyarakat seputar Kabupaten Pangandaran.

"Dimensi Cognitive Effectiveness (Keefektifan Memperoleh Pengetahuan). Dimensi ini menunjukkan bahwa informasi yang disampaikan oleh sender kepada receiver melalui Computer Mediated Communication mampu menambah dan memperkaya pengetahuan secara efektif mengenai informasi yang dibutuhkan" (Darmawan 2013, 135).

Berdasarkan data penelitian, sebanyak 52 responden $(52,2 \%)$ menyatakan informasi yang diberikan pemerintah daerah sesuai dengan kebutuhan karena informasinya membantu dalam proses pemecahan masalah. Informasi yang diberikan harus relevan sehingga dapat memberikan manfaat bagi masyarakat. Jika informasi tersebut tidak relevan, informasi tersebut tidak akan berguna. Relevansi informasi merupakan salah satu nilai informasi yaitu sifat kecocokan.

"Sifat ini menunjukkan seberapa baik keluaran informasi dalam hubungannya dengan permintaan para pemakai. Isi informasi harus ada hubungannya dengan masalah yang sedang dihadapi sedangkan semua keluaran tidak berguna. Sifat ini sulit untuk diukur" (Sutabri 2005, 30).

Berdasarkan data penelitian sebanyak 72 responden $(72,2 \%)$ menyatakan termotivasi untuk mencari informasi dengan kegiatan karena informasi yang diberikan selalu update sehingga bisa menjadi tahu banyak informasi tentang Kabupaten Pangandaran.
Hal ini berarti penyebaran informasi pemerintah daerah selalu menyajikan informasi setiap minggu, sehingga mampu menumbuhkan dorongan pemenuhan informasi masyarakat seputar Kabupaten Pangandaran.

Berdasarkan data penelitian, sebanyak 65 responden $(65,7 \%)$ menyatakan bahwa kegiatan pariwisata untuk menumbuhkan kreativitas mampu memenuhi kebutuhan informasi terbaru, karena pemerintah berusaha menampilkan informasi sehingga dapat menambah pengetahuan seputar Kabupaten Pangandaran. Sedangkan sebanyak 48 responden $(48,5 \%)$ menyatakan bahwa pihak pemerintah daerah Kabupaten Pangandaran mampu memenuhi kebutuhan informasi rutin, karena informasi tersedia setiap hari dan selalu berubah sesuai dengan kejadian aslinya. Sebanyak 47 responden $(47,5 \%)$ menyatakan bahwa mampu memenuhi kebutuhan informasi secara mendalam, karena informasinya disampaikan secara detail (mencantumkan keterangan waktu, tempat, dan gambar). Sedangkan sebanyak 67 responden $(67,7 \%)$ menyatakan bahwa pemerintah daerah Kabupaten Pangandaran mampu memenuhi kebutuhan informasi secara ringkas atau singkat tapi lengkap, karena informasi yang keluar menggunakan gaya bahasa yang jelas dan berasal dari sumber terpercaya.

\section{G. KESIMPULAN}

Informasi kebutuhan informasi wisata sudah mampu memenuhi kebutuhan informasi seputar wisata Kota Bandung, meskipun belum semua informasi tersedia pada saat diperlukan. Informasi yang diberikan cepat diterima oleh receiver dan informasinya bersifat akurat, sehingga dapat memenuhi kebutuhan informasi seputar wisata Kota Bandung. Jumlah informasi yang diperoleh melalui kebutuhan informasi wisata sudah melengkapi semua informasi yang dibutuhkan, sehingga dapat memenuhi kebutuhan jumlah informasi wisata yang diperlukan.

Setelah mengakses kebutuhan informasi wisata seputar wisata Kota Bandung dapat bertambah, sehingga kebutuhan informasi seputar wisata Kota Bandung dapat terpenuhi.

Informasi yang diberikan sudah sesuai dengan kebutuhan pengguna dan informasi yang diberikan bermanfaat, sehingga dapat memenuhi kebutuhan informasi seputar wisata Kota Bandung.

Informasi yang diberikan mampu menumbuhkan keinginan untuk memahami dan menerapkan informasi, sehingga kebutuhan informasi seputar wisata Kota Bandung dapat terpenuhi. 


\section{DAFTAR PUSTAKA}

Allan. 2005. Understanding how technology paradoxes affect in internet service quality. Internet research electronic networking application and policy. digilib.unila.ac.id. (Diakses pada $26 \mathrm{Mei}$ 2016)

Arikunto, Suharsimi. 2010. Prosedur Penelitian Suatu Pendekatan Praktik. Yogyakarta: Rineka Cipta.

Arsanto, Putera Setya. 2014. Peranan Penggunaan Website Supersoccer.co.id Terhadap Pemenuhan Kebutuhan Informasi Sepakbola Anggota Cosmic. Jatinangor: Departemen Ilmu Informasi dan Perpustakaan Fikom UNPAD

Boyd, Danah M dan Nicole B. Ellison. 2007. Social Network Sites: Definition, History, and Scholarship. Journal of Computer-Mediated Communication Volume 13, Issue 1, Pages 210 230, October 2007, http://onlinelibrary.wilev.com/doi/10.1111/i.10 83-6101.2007.00393.x/full. (Diakses tanggal 11 $\underline{\text { Juli 2015) }}$

Bungin, Burhan. 2008. Metodologi Penelitian Kuantitatif : Komunikasi, Ekonomi, dan Kebijakan Publik Serta Ilmu-ilmu Sosial Lainnya. Jakarta: Kencana

Darmawan, Deni. 2013. Pendidikan Teknologi Informasi Dan Komunikasi Teori dan Aplikasi. Bandung: Remaja Rosdakarya.

Handoko, Martin. 1992. Motivasi : Daya Penggerak Tingkah Laku. Yogyakarta: Kanius.

Hartono, Jogiyanto. 2002. Analisis \& Desain Sistem Informasi: Pendekatan Terstruktur Teori dan Praktik Aplikasi Bisnis. Yogyakarta: Andi.

Kadir, Abdul. 2002. Pengenalan Sistem Informasi. Yogyakarta: Andi Offset.

Kaplan, Andreas dan Michael Haenin. 2010. Users of the world, unite! The challenges and opportunities of Social Media. Business Horizons $53(1)$ : 59-68. http://id.m.wikipedia.org/wiki/Media Sosial. (Diakses pada 26 Mei 2016)

Kusuma, Yuliandi. 2009. Pintar Twitter. Jakarta: Grasindo.
Ladjamudin, bin Al-Bahra. 2005. Analisis dan Desain Sistem Informasi Edisi Pertama. Yogyakarta: Penerbit Graha Ilmu.

Mukrimah, Sofiati. Ini 9 Alasan Twitter Tetap Menjadi Sosial Media Favorit Bagi Banyak Orang. Bagaimana Menurutmu?. www.trivia.id/post/ini-7-alasan-kenapa-twittertetap-menjadi-sosial-media-favorit. (Diakses tanggal 26 Mei 2016)

Rakhmat, Jalaluddin. 2009. Metode Penelitian Komunikasi. Bandung: Remaja Rosdakarya.

Singarimbun, Masri dan Sofian Effendi, 1989. Metode Penelitian Survai Edisi Revisi. Jakarta: Pustaka LP3ES.

Sugiyono. 2009. Metode Penelitian Kuantitatif Kualitatif Dan R\&D. Bandung: Alfabeta.

Sukmadinata, Nana Syaodih. 2006. Metode Penelitian Pendidikan. Bandung: Remaja Rosda Karya.

Sutabri, Tata. 2012. Analisis Sistem Informasi. Jakarta: Penerbit Andi.

Wasserman, Tood. 2012. Twitter Co-Founder: Spending Too Much Time On the Site is 'Unhealthy'.

http://mashable.com/2012/02/24/biz-stonetweeting-too-much-unhealthy/\#03N.buh3yPqz. (Diakses tanggal 20 Maret 2016)

Web, Jurnal. 2015. 3 Hal Ini Yang Dilakukan Orang Indonesia di Twitter. www.jurnalweb.com/halini-yang-dilakukan-orang-indonesia-di-twitter/. (Diakses tanggal 20 Maret 2016)

Wiratri, Lanjar. 2015. Twitter Keluarkan Aturan Baru untuk Direct Message. www.okezone.com/read/2015/04/21/1137800/t witter-keluarkan-aturan-baru-untuk-directmessage. (Diakses tanggal 20 Maret 2016)

Yusup, Pawit M. 2009. Ilmu Informasi, Komunikasi, dan Kepustakaan. Jakarta: Bumi Aksara.

Yusup, Pawit M. 2010. Teori dan Praktik Penelusuran Informasi (Information Retrieval). Jakarta: Kencana.

Yusup, Pawit M. 2012. Perspektif Manajemen Pengetahuan Informasi, Komunikasi, Pendidikan, dan Perpustakaan. Jakarta: Rajawali Pers. 